Котик О. В. [1; ORCID ID: 0000-0002-2749-4472], старший викладач,

Хібеба Б. М. [1; ORCID ID: 0000-0001-8489-1696], здобувач вищої освіти першого (бакалаврського) рівня

${ }^{1}$ Національний університет водного господарства та природокористування, м. Рівне

\title{
КОРПОРАТИВНІ КОНФЛІКТИ В АКЦІОНЕРНИХ ТОВАРИСТВАХ ТА ШЛЯХИ їХ ПОДОЛАНнЯ
}

У статті розглянуто зміст поняття «корпоративний конфлікт», розмежовано його значення 3 «конфліктом інтересів». Проаналізовано взаємозв'язок між ними, а також визначено суб'єкти корпоративних відносин та типи конфліктів, що між ними виникають. Проведено дослідження передумов та причин виникнення корпоративних конфліктів в акціонерних товариствах, а також здійснений аналіз методів й правових засобів щодо їх вирішення. Визначено шляхи подолання та попередження появи В акціонерному товаристві корпоративних конфліктів.

Ключові слова: корпоративний конфлікт; конфлікт інтересів; корпоративні відносини; суб'єкти корпоративних конфліктів; акціонерне товариство.

Постановка проблеми. Останніми роками збільшується кількість корпоративних конфліктів у сфері діяльності одного 3 ключових суб'єктів сучасного підприємництва - акціонерного товариства. Здійснення акціонерним товариством підприємницької діяльності, успішне вирішення завдань і досягнення цілей, поставлених перед акціонерним товариством при його створенні, можливі лише при наявності в ньому умов для попередження та врегулювання корпоративних конфліктів - конфліктів між учасниками корпоративних відносин.

Аналіз останніх досліджень і публікацій. Аналіз наукових джерел засвідчив, що за останні роки все більша кількість вчених приділяє свою увагу дослідженню корпоративних конфліктів в акціонерних товариствах. Питання шляхів їх подолання викликає інтерес як серед науковців, так і серед широких верств населення. Зокрема, у даній статті використано напрацювання наступних авторів: Величко 0., Янковська Т., Вінник О. М., Гаврилко П. П., 
Кужелєв М. О., Брітченко І. Г., Галацевич Н. С., Данельян А. А., Жорнокуй Ю. М., Л Лаговська О. А., Л Леось О. Ю., Х Хмельницька В. П., Очкалова М. Ю., Холод В. В., Резнікова Л. С.

Як показав огляд наукових джерел, дослідженню аспектів корпоративних конфліктів присвячена чимала кількість літератури, але існує необхідність поглиблення наукових напрацювань у сфері їх вирішення в акціонерному товаристві, що обґрунтовує актуальність даної статті.

Постановка завдання. Метою статті $\epsilon$ дослідження корпоративних конфліктів в акціонерних товариствах: визначення основних причин появи, шляхів подолання та попередження їх виникнення.

Виклад основного матеріалу. Розглядаючи корпоративні конфлікти в межах акціонерного товариства (далі - АТ), насамперед доцільним буде з'ясувати значення основних понять, на яких саме i буде базуватися дане дослідження.

За своєю суттю, конфлікт - зіткнення протилежних інтересів і поглядів, напруження і крайнє загострення суперечностей, що призводить до активних дій, ускладнень, боротьби; ситуація, в якій кожна зі сторін намагається зайняти позицію несумісну з інтересами іншої сторони [1, С. 8].

Поняття «корпоративний конфлікт» не $є$ чітко окресленим i використовується у різних значеннях в економічній, обліковій та нормативно-правовій літературі. Розглянувши достатню кількість трактувань серед вчених і науковців, можна визначити три основні погляди:

-це істотні розбіжності між акціонерами АТ і самим товариством в особі його органів управління та посадових осіб, а також між акціонерами АТ;

-це порушення норм чинного законодавства, статуту чи внутрішніх документів товариства, прав акціонерів чи групи акціонерів, позови до товариства, його органів управління чи по суті рішень, які вони ухвалювали;

- це боротьба суб'єктів корпоративних відносин за матеріальні та нематеріальні ресурси акціонерних товариств із використанням усіх наявних у них інструментів та методів впливу [8, С. 172].

Корпоративний конфлікт $€$ різновидом конфлікту інтересів. Слід відрізняти дані терміни, адже конфлікт інтересів $€$ родовим поняттям та може виникати щодо будь-яких учасників корпоративних відносин. Тобто він відбувається за участю кількох, двох чи навіть щодо однієї особи - так звані внутрішньо-особистісні конфлікти, 
пов'язані з виконанням однією особою різних рольових функцій: акціонера, посадової особи АТ, члена наглядової ради організаціїконкурента.

Щодо корпоративних - це видове поняття, оскільки виникають лише між суб'єктами корпоративних відносин як носіями корпоративних інтересів - загальнокорпоративного (до них належать: товариство, його органи, посадові особи), так i індивідуально-корпоративних (засновники, учасники/акціонери), i зазвичай характеризуються більш-менш активною поведінкою учасників конфлікту чи одного з них [2, С. 6].

На відміну від корпоративного конфлікту термін «конфлікт інтересів» означає не ситуацію корпоративного конфлікту, а ситуацію, що має високу вірогідність його виникнення, при якій особиста зацікавленість людини може вплинути на процес ухвалення рішення і таким чином принести шкоду інтересам товариства або компанії.

Можливість усвідомити питання, пов'язані з визначенням видів корпоративних конфліктів та можливість відмежувати їх від поняття «конфлікт інтересів» дає суб'єктний склад учасників корпоративних відносин.

Суб'єкти корпоративних конфліктів - це учасники корпоративних конфліктів, які мають фінансовий інтерес, що пов'язаний 3 діяльністю підприємства. Українське законодавство оперує декількома поняттями стосовно осіб, які беруть участь у створенні та діяльності АТ і вважаються суб'єктами корпоративних правовідносин. Так, за Законом України «Про акціонерні товариства» такими особами пропонується визнавати засновників АТ, акціонерів, інвесторів та номінального утримувача акцій [7].

Таким чином, залежно від суб'єктного складу можна виокремити кілька типів корпоративних конфліктів, які можуть впливати на фінансово-господарську діяльність компаній. Вони виникають між:

1) мажоритарними й міноритарними акціонерами. Великі акціонери можуть диктувати умови при здійсненні угод, що суперечать інтересам акціонерного товариства та дрібних власників. Ключовим аспектом протистояння $€$ спонукання мажоритарних акціонерів до викупу акцій;

2) акціонерами й органами управління товариством (основний аспект протистояння - боротьба за керівні посади органів управління товариством); 
3) різними органами управління юридичної особи (основний аспект протистояння - визначення повноважень;

4) інвестором (потенційним акціонером) і мажоритарними акціонерами у зв'язку 3 поглинанням ззовні (основний аспект протистояння - боротьба за контроль над товариством);

5) між арбітражним керуючим юридичної особи, що перебуває на ранніх стадіях процедури банкрутства, і акціонерами компанії [6, C. 73].

Вищенаведені види конфліктних ситуацій $\epsilon$ досить різноманітними. Однак варто розуміти, що корпоративний конфлікт $€$ похідним від регулятивних корпоративних відносин, тобто учасниками конфліктної ситуації можуть бути лише учасники корпоративних відносин. Це свідчить про те, що учасниками (сторонами) корпоративного конфлікту в акціонерному товаристві $€$ саме товариство, члени його органів та акціонери.

Основною передумовою корпоративного конфлікту $\epsilon$ протиріччя, що виникають між інтересами суб'єктів корпоративних відносин. Зокрема, підставами виникнення корпоративного конфлікту вважають: конфлікт інтересів; інтереси самого товариства; порушення прав учасників товариства стосовно корпоративного управління (контролю); оцінка якості та ефективності корпоративного управління або права спільного володіння бізнесом; порушення прав чи корпоративних інтересів суб'єктів корпоративних відносин або створення загрози такого порушення.

У контексті дослідження корпоративних конфліктів в акціонерних товариствах необхідно з'ясувати не лише підстави, а й причини виникнення корпоративних конфліктів.

Серед науковців існують чисельні підходи до окреслення причин виникнення корпоративних конфліктів. Як правило, основними з них визначають:

1) юридико-технічна недосконалість та колізії чинного законодавства;

2) порушення законодавства та локальних актів;

3) невиконання договірних зобов'язань;

4) протиріччя інтересів учасників корпоративних правовідносин, обумовлені особливостями організаційно-правової форми AT;

5) прагнення до економічного панування у формі корпоративних захоплень;

6) зведення особистих рахунків;

7) специфіка відносин власності в АT; 
8) нерівність права акціонерів [4, С. 159].

Якщо розглядати детальніше корпоративні конфлікти в акціонерному товаристві, то перший, основний принцип корпоративного конфлікту $€$ одним із джерел організаційного i економічного розвитку АТ. Такі конфлікти закладені в самій природі AT.

Найважливішими особливостями організаційно-правової i економічної природи класичного АТ, що неминуче породжують конфлікти різної величини і виду, є:

-наявність низки самостійних акціонерів-співвласників, економічні підходи та інтереси яких щодо АТ не збігаються;

- різна кількість акцій, якими володіють акціонери, i, як наслідок, різний обсяг їх відповідних прав у АТ, контролю над АТ і ризиків інвестування в АТ;

- «поділ влади» В АТ на «законодавчу» (загальні збори акціонерів, наглядову раду), «виконавчу» (правління) і «судову» (ревізійна комісія);

-відмежування «реальних» власників (акціонерів) від «реальної» власності (майна АТ) за допомогою інститутів акції i юридичної особи (АТ);

-наявність власників-акціонерів і найманих працівників (керівництво, інший персонал АТ);

-взаємодія AТ, його акціонерів і менеджерів із широким колом контрагентів, економічні підходи й інтереси яких щодо АТ не збігаються з інтересами АТ (господарюючі суб'єкти, влада, засоби масової інформації, політичні групи тощо) [10].

Основними видами порушень прав акціонерів в Україні i країнах з ринками цінних паперів, що розвиваються, $\epsilon:$ права акціонера на участь в загальних зборах і в ході реорганізації i консолідації компаній, «розмивання» капіталу, виведення активів i трансфертне ціноутворення, порушення вимог розкриття інформації, здійснення угод з порушенням встановленого порядку, здійснення фіктивних банкрутств 3 подальшим скуповуванням активів, що продаються.

Усе вищезазначене визначає об'єктивну необхідність розробки механізму вирішення корпоративних конфліктів.

Існує безліч методів вирішення конфліктів, таких як ухилення, згладжування, примушення, компроміс чи вирішення проблеми. Але розглянемо два основні блоки, на які поділяється вирішення 
корпоративних конфліктів у акціонерних товариствах, - це внутрішній та зовнішній.

Перший - внутрішній, передбачає врегулювання конфліктних ситуацій самими учасниками корпоративних відносин за допомогою існуючих правових методів і процедур. Зазвичай відбувається добровільне відновлення порушеного права, коли особа не має потреби звертатися до юрисдикційного органу. Суб'єкти прав на власний розсуд здійснюють належні їм цивільні права та можуть самостійно вирішити конфлікт у позасудовому порядку або шляхом застосування альтернативних процедур його розв'язання.

Натомість другий - зовнішній, представлений судовим порядком розгляду відповідних конфліктних ситуацій. Він є найбільш ефективним засобом вирішення корпоративних конфліктів [6, С. 289].

Судова процедура вирішення корпоративних конфліктів забезпечує, як правило, їх мирне припинення 3 використанням елементу сили у вигляді державного примусу, оскільки йому зобов'язані підкоритися сторони, які перебувають у стані протиборства. 3 цього приводу передусім важливим $€$ те, що захист прав має бути побудований таким чином, щоб забезпечувалися корпоративні інтереси акціонера та AT, які вони пов'язують із закріпленими за ними суб'єктивними корпоративними правами та/або корпоративними інтересами.

Судовий порядок вирішення корпоративного конфлікту має ряд переваг: а) розгляд конфлікту незалежним органом, який за своїм призначенням і становищем повинен бути незацікавлений у результаті справи; б) чітко розроблена процедура встановлення і перевірки фактичних обставин та прийняття рішень; в) нормативна основа діяльності суду, який керується законом і власним переконанням; г) обов'язковість прийнятих рішень для виконання як сторонами конфлікту, так й іншими особами [5, С. 145].

Серед наразі чинних правових засобів щодо розвязання конфліктів в акціонерному товаристві виділяють:

1. внутрішньокорпоративні механізми: розгляд таких конфліктів на загальних зборах акціонерів, наглядовою радою, виконавчим органом, за участі ревізійної комісії, ревізора та/або аудитора в передбаченому законом та/або статутом АТ порядку;

2. розв'язання конфлікту компетентними державними органами в межах наданих їм повноважень у разі, якщо корпоративний конфлікт зачіпає публічні інтереси на ринку цінних паперів: наприклад, щодо порушення установлених вимог розміщення додаткових акцій, у результаті якого зменшуються частки окремих чи навіть багатьох акціонерів у статутному капіталі 90 
АТ та ін.;

3. судові процедури, передбачені чинним законодавством, які застосовуються в разі неефективності чи неможливості використання вищезгаданих процедур за ініціативою хоча б одного 3 учасників конфлікту [2, С. 7].

За таких умов, важливим є дослідження не тільки способів вирішення та розв'язання корпоративних конфліктів, а й запобігання їх появи в акціонерному товаристві.

Щодо ефективних способів запобігання корпоративних конфліктів можна віднести:

-посилення відповідальності за порушення законодавства в галузі корпоративного управління;

-підвищення корпоративної культури суб'єктів корпоративних відносин;

-удосконалення державного механізму регулювання у сфері корпоративного управління;

-підвищення результативності діяльності рад директорів акціонерних товариств;

-прийняття й активне впровадження як національних, так і міжнародних кодексів та стандартів корпоративного управління [3, C. $43 ; 9]$.

Попередженню корпоративних конфліктів сприяє точне й безумовне дотримання суспільством норм чинного законодавства, правил корпоративної культури, виконання соціальних стандартів, а також сумлінна поведінка усіх суб'єктів корпоративних відносин.

Слід зазначити, що діюче законодавство не встановлює вимог щодо обов'язкового дотримання будь-яких досудових процедур 3 метою запобігання корпоративних конфліктів. Застосування таких процедур значною мірою залежить від бажання самого акціонерного товариства: відповідні норми можуть і повинні бути включені в Статут корпорації або в його внутрішні документи. Крім того, корпорація може стати підписантом міжнародних угод та асоціацій (наприклад Глобального договору ООН тощо).

Діагностика й запобігання корпоративних конфліктів дозволяють забезпечити дотримання й захист прав власників, а також інтересів й ділової репутації акціонерного товариства, що позитивно впливає на ії імідж і $\epsilon$ важливим індикатором для потенційних інвесторів.

Висновки. Досліджуючи сутність та природу походження корпоративних конфліктів в акціонерному товаристві, насамперед було визначено базові поняття щодо об'єкта дослідження. На підставі узагальнення наукових поглядів уточнено зміст категорії 
«корпоративний конфлікт». Розмежовано економічну й філософську природу таких понять, як «корпоративний конфлікт» і «конфлікт інтересів», а також проаналізовано основні типи конфліктів, що виникають між суб'єктами корпоративних відносин. З'ясовано передумови та причини виникнення корпоративних конфліктів, визначено методи та правові засоби їх вирішення в акціонерному товаристві. Зазначено основні способи запобігання та попередження появи корпоративних конфліктів в акціонерному товаристві, що створює надійне підґрунтя для злагодженої та безконфліктної діяльності.

Загальний висновок, який дозволяє зробити проведене дослідження, полягає в тому, що спектр корпоративних конфліктів досить широкий і динамічний. Попередженню і врегулюванню корпоративних конфліктів сприяє точне і безумовне дотримання акціонерним товариством законодавства, а також його сумлінна і розумна поведінка у взаєминах з усіма учасниками корпоративних відносин.

1. Величко 0., Янковська Т. Управління конфліктами та стресом : посібник для працівників апарату суду. Київ, 2010.192 с. 2. Вінник О. М. Корпоративні конфлікти та зловживання корпоративними правами в акціонерних товариствах: традиційні та інноваційні способи попередження й розв'язання. Актуальні питання інноваційного розвитку. Вид-во «Юрайт», 2012. № 2. С. 5-12. 3. Гаврилко П. П., Кужелєв М. О., Брітченко І. Г. Корпоративні відносини в банківському секторі: фінансові механізми та маркетингові стратегії : монографія. Рівне - Новий Сонч : Волин. обереги, 2016. 228 с. 4. Галацевич Н. С. Актуальні способи розв'язання корпоративних конфліктів. Порівняльно-аналітичне право. 2018. № 4. С. 158-160. 5. Данельян А. А. Корпорація та корпоративні конфлікти. М. : Камерон, 2007. 192 с. 6. Жорнокуй Ю. М. Цивільно-правова природа корпоративних конфліктів в акціонерних товариствах : дис. ... д-ра юрид. наук : 12.00.03. Харків, 2016. 476 с. 7. Про акціонерні товариства : Закон України. Відомості Верховної Ради України (ВВP). 2008. № 50-51. Ст. 384. 8. Лаговська О. А., Шайдецька І. І. Корпоративні конфлікти та інформаційна асиметрія: причини і шляхи подолання. Економічний аналіз : зб. наук. праць. Тернопіль : Видавничо-поліграфічний центр ТНЕУ «Економічна думка», 2016. Том 26. № 1. С. 170-178. 9. Леось О. Ю., Хмельницька В. П., Очкалова М. Ю. Шляхи регулювання корпоративних відносин у системі управління підприємствами. ДонДУУ. 9 с. URL: http://www.dridu.dp.ua/zbirnik/2012-01(7)/12loysup.pdf (дата звернення: 18.03.2021). 10. Холод В. В., Резнікова Л. С. Корпоративні конфлікти та шляхи їх подалання. ДОННУЕT. URL: http://www.rusnauka.com/31_PRNT_2010/Economics/73501.doc.htm (дата звернення: 18.03.2021).

\section{REFERENCES:}

1. Velychko 0., Yankovska T. Upravlinnia konfliktamy ta stresom : posibnyk dlia pratsivnykiv aparatu sudu. Kyiv, 2010. 192 s. 2. Vinnyk 0. M. Korporatyvni konflikty ta zlovzhyvannia korporatyvnymy pravamy $v$ aktsionernykh tovarystvakh: tradytsiini ta 
innovatsiini sposoby poperedzhennia y rozviazannia. Aktualni pytannia innovatsiinoho rozvytku. Vyd-vo «lurait», 2012. № 2. S. 5-12. 3. Havrylko P. P., Kuzheliev M. O., Britchenko I. H. Korporatyvni vidnosyny $v$ bankivskomu sektori: finansovi mekhanizmy ta marketynhovi stratehii : monohrafiia. Rivne - Novyi Sonch : Volyn. oberehy, 2016. 228 s. 4. Halatsevych N. S. Aktualni sposoby rozviazannia korporatyvnykh konfliktiv. Porivnialno-analitychne pravo. 2018. № 4. S. 158-160. 5. Danelian A. A. Korporatsiia ta korporatyvni konflikty. M. : Kameron, 2007. 192 s. 6. Zhornokui Yu. M. Tsyvilno-pravova pryroda korporatyvnykh konfliktiv $v$ aktsionernykh tovarystvakh : dys. ... d-ra yuryd. nauk : 12.00.03. Kharkiv, 2016. 476 s. 7. Pro aktsionerni tovarystva : Zakon Ukrainy. Vidomosti Verkhovnoi Rady Ukrainy (VVR). 2008. № 50-51. St. 384. 8. Lahovska 0. A., Shaidetska I. I. Korporatyvni konflikty ta informatsiina asymetriia: prychyny i shliakhy podolannia. Ekonomichnyi analiz : zb. nauk. prats. Ternopil : Vydavnycho-polihrafichnyi tsentr TNEU «Ekonomichna dumka», 2016. Tom 26. № 1. S. 170-178. 9. Leos 0. Yu., Khmelnytska V. P., Ochkalova M. Yu. Shliakhy rehuliuvannia korporatyvnykh vidnosyn u systemi upravlinnia pidpryiemstvamy. DonDUU. 9 s. URL: http://www.dridu.dp.ua/zbirnik/2012-01(7)/12loysup.pdf (data zvernennia: 18.03.2021). 10. Kholod V. V., Reznikova L. S. Korporatyvni konflikty ta shliakhy yikh podalannia. DONNUET.

URL: http://www.rusnauka.com/31_PRNT_2010/Economics/73501.doc.htm

(data zvernennia: 18.03.2021).

Kotyk O. V. [1; ORCID ID: 0000-0002-2749-4472], Senior Lecturer,

Khibeba B. M. [1; ORCID ID: 0000-0001-8489-1696], Applicant for higher education of the first (bachelor's) level

${ }^{1}$ National University of Water and Environmental Engineering, Rivne

\section{CORPORATE CONFLICTS IN JOINT STOCK COMPANIES AND WAYS TO RESOLVE THEM}

The article considers the meaning of the concept of "corporate conflict". Among the large number of interpretations among scientists, identified three main views on this concept. It is studied that corporate conflict is a kind of conflict of interest. The meaning of the terms "conflict of interest" and "corporate conflict" is distinguished, the relationship between them is analyzed. The subjective composition of the participants of corporate relations in relation to the joint-stock company is determined. The types of corporate conflicts depending on the subject composition, which may affect the financial and economic activities of companies, are considered. The bases of occurrence of corporate conflicts in joint-stock companies are defined. The main approaches to the causes of corporate conflicts are outlined. The most important features of the organizational, legal and economic nature of the classical joint-stock company, which inevitably give rise to conflicts of various sizes and types, are identified. The main types of violations of shareholders' rights in Ukraine and countries with emerging securities markets have been identified. The objective necessity of 
developing a mechanism for resolving corporate conflicts is substantiated. Defined the two main blocks into which the resolution of corporate conflicts in joint-stock companies is divided are internal and external. It has been studied that the judicial procedure for resolving is the most effective means of resolving corporate conflicts and has a number of advantages. The current legal remedies for resolving conflicts in a joint-stock company are highlighted. Not only ways to resolve and resolve corporate conflicts, but also to prevent them from occurring in a joint stock company have been explored.

Diagnosis and prevention of corporate conflicts allow to ensure the observance and protection of the rights of owners, as well as the interests and business reputation of the company, which has a positive impact on its image and is an important indicator for potential investors.

Keywords: corporate conflict; conflict of interest; corporate relations; subjects of corporate conflicts; joint stock company.

\section{Котик О. В. [1; ORCID ID: 0000-0002-2749-4472], старший преподаватель кафедры финансов и экономической \\ безопасности, \\ Хибэба Б. Н. [1; ORCID ID: 0000-0001-8489-1696], соискатель высшего образования первого (бакалаврской) уровня \\ ${ }^{1}$ Национальный университет водного хозяйства и природопользования, г. Ровно}

\section{КОРПОРАТИВНЫЕ КОНФЛИКТЫ В АКЦИОНЕРНОМ ОБЩЕСТВЕ И ПУТИ ИХ ПРЕОДОЛЕНИЯ}

В статье определено содержание понятия «корпоративный конфликт», разграничены его значение с «конфликтом интересов». Проанализирована взаимосвязь между ними, а также определены субъекты корпоративных отношений и типы конфликтов, которые между ними возникают. Проведено исследование причин возникновения корпоративных конфликтов в акционерных обществах, а также осуществлен анализ методов и правовых средств по их решению. Определены пути преодоления и предупреждения появления В акционерном обществе корпоративных конфликтов.

Ключевые слова: корпоративный конфликт; конфликт интересов; корпоративные отношения; субъекты корпоративных конфликтов; акционерное общество. 